\title{
Forme ale organizării vieții monahale și ale misiunii mănăstirii promovate de Sfântul Nil Sorski
}

\author{
Alexandru CUȚCHI*
}

Abstract: Saint Nil Sorski appears, probably, like that the most important figure in systematic promotion of learning and practicing contemplative silence in medieval Russian spiritual tradition. Saint Nil brought to Russia from Mount Athos the practice of life in smaller communities (lifestyle of sketes), causing a high hesychast current in the spirit of total monastic poverty (the movement of non-possessors) and of the monks' non-engagement in social and political life. He saw in this new form of monastic life (intermediate between cenobitism and heremitism) the chance of a more solitary life in which monks could more fully respect their religious vows, avoiding the temptation of materialism which monasteries that owned properties were exposed to. The works of this great teacher of Russian monasticism give in detail also a theory of moral perfection, on which "the great prior" wanted to rebuild the Russian monastic life.

\footnotetext{
"PhD Candidate, Faculty of Orthodox Theology at "București" University in Bucharest, Romania.
} 


\section{Alexandru CUȚCHI}

Keywords: monasticism, hesychasm, skete, spirituality, pastoral mission, consummation

\section{Preliminarii. Tradiția isihastă pe pământul rusesc}

Spiritualitatea Bisericii Ruse a fost dintotdeauna modelată în special de tradiția bizantină. Însă, dacă unul dintre aspectele ce au caracterizat perioada kieveană (secolele IX-XIII) a fost lipsa unei tradiții mistice în literatura rusă, epoca medievală rusă (perioada mongolă - secolele XIII-XV) își îmbogățește tradiția religioasă printr-o caracteristică esențială - isihasmul - care și-a găsit drumul spre Rusia de la mănăstirile athonite în secolele XIV și XV, practic concomitent cu apogeul renașterii isihaste în Bizanț. Astfel apare în Rusia un tip contemplativ de monahism bazat pe asceză, rugăciunea minții și comuniunea mistică cu Dumnezeu².

Răspândirea acestuia s-a produs prin diverse căi: prin ucenicii slavi ai Sfântului Grigore Sinaitul (1255-1346) de la mănăstirea Paroria din munții Traciei, prin numărul mare de pelerini ce vizitau Constantinopolul și Muntele Athos, prin soli speciali cum au fost cei trimiși de Sfântul Serghie de Radonej în Bizanț pentru a intra în contact cu isihasmul. Mai apoi, stilul duhovnicesc al „Tebaidei Nordului” așa cum deseori erau numite mai târziu pământurile rusești din nord în secolele XV-XVI, presărate cu nenumărate mănăstiri - a absorbit într-o mare măsură influențele isihaste ${ }^{3}$; și deja la granița secolelor XV-XVI își face apariția „Predania” sau „Testamentul către ucenici”

\footnotetext{
${ }^{2}$ Vezi G. P. Fedotov, A Treasury of Russian Spirituality, New York, 1948, http:// www.holytrinitymission.org/ books/english/russian_spirituality_fedotov.htm\# Toc46671173 (accesat pe 28 mai 2015).

${ }^{3}$ După apariția cărții Русская Фиваида на Севере (Tebaida Rusească a Nordului) a scriitorului rus Andrei Muraviev (Андрей Муравьёв, Русская Фиваида на Севере, Санкт-Петербург, 1855), termenul „Tebaida Nordului” a devenit denumirea poetică a pământurilor rusești din nord, în comparație cu regiunea egipteană veche Tebaida care era recunoscută prin numărul mare de pustnici eremiți stabiliți acolo.
} 
al Sfântului Nil Sorski, ,primul text original al isihasmului rus"4. Viaţa şi scrierile Sfântului Nil - singurul reprezentant literat al numeroșilor isihaști tăcuți din pădurile din nordul Rusiei -, ca și întreaga mișcare a călugărilor de dincolo de râul Volga inițiată de acesta constituie dezvoltarea și continuarea cea mai pură și nemijlocită a tradiției isihaste pe pământul rusesc.

„Acest curent este continuarea (nu doar reflectarea) vie și organică a acelei mișcări duhovnicești și contemplative care a cuprins întreaga lume greacă și pe cea a slavilor de sud în secolul XIV. Era, mai intâi de toate, renașterea monahismului contemplativ... Adevărul miş̧ării duhovnicești a pustnicilor ,,de dincolo de râul Volga" este... adevărul contemplației, adevărul rugăciunii minţii’’s.

$\mathrm{O}$ a doua direcție luată de monahismul rus în acea perioadă, pe lângă cea mistică, a fost una socială, care culmina cu Sfântul Iosif de Volokolamsk ${ }^{6}$. Reprezentanții acesteia erau mai activi și practici, oferind sprijin prinților moscoviți în vederea construirii unui stat unificat. Conflictul dintre cele două tabere, reprezentanții cărora au primit numele de posesori (iozefiți) și non-posesori, a izbucnit la începutul secolului al XVI-lea, atunci când aceștia s-au contrazis violent pe cele două mari probleme ale momentului: problema legitimității proprietăților mănăstirești, precum și cea a politicii care trebuie să fie adoptată în relația cu noul grup de eretici - ereticii iudaizanți. Biserica, însă, în cele din urmă, va considera ca fiind acceptabile ambele forme de monahism, declarându-i sfinți pe liderii celor două tabere?

\footnotetext{
${ }^{4}$ С. С. Хоружий, $O$ старом и новом, Алетейя, Санкт-Петербург, 2000, pp. 220-221.

${ }^{5}$ Г. В. Флоровский, Пути русского богословия, Париж, 1983, pp. 20-21.

${ }^{6}$ Vezi Thomas Špidlik, Joseph de Volokolamsk; un chapitre de la spiritualité russe, în „Orientalia Christiana Analecta”, vol. 146, Roma, 1956.

${ }^{7}$ Vezi G. P. Fedotov, The Russian Religious Mind, II, Cambridge, MA, 1946, pp. 265-284.
} 


\section{SFÂNTUL CUVIOS NIL SORSKI - PEDAGOG AL MONAHISMULUI RUS}

\section{Viața și opera}

Sfântul Nil Sorski (1433 - 1508) a fost un mare pedagog al monahismului rus, întemeietor al vieţii monahale de schit (idioritmice) din Rusia secolului al XV-lea, precum şi al mișcării care s-a opus posesiunii de proprietăți bisericești și implicării monahilor în viața politică, reprezentanții căreia au primit numele de non-posesori. El apare, probabil, ca şi cea mai importantă figură în promovarea sistematică a învățării și practicării tăcerii contemplative în tradiția spirituală rusă medievală. Născut într-o familie nobilă din Moscova și fiind bine educat, Nil a intrat de tânăr în viața monahală, fiind călugărit în mănăstirea Sfântului Chiril de Belozersk (Lacul Alb) în anii '50-'60 ai secolului al XV-lea'.

Nil Sorski se ruga și postea mult, se ținea departe de toate cele ale lumii, încerca să-i imite întru toate pe părinții din vechime, căutânduși îndrumare și instruire atât în viețile, cât și în scrierile lor. Având un mare interes pentru asceză și rugăciunea isihastă și, simțindu-se neîmplinit aici, pleacă împreună cu ucenicul său Inochentie într-un pelerinaj de mai mulți ani la Constantinopol și la Muntele Athos. Acolo dobândește învățătura despre viața ascetică, rugăciunea inimii, trezvia cugetului și păzirea inimii. În Athos, Nil s-a dedicat citirii, traducerii şi studierii scrierilor Sfinților Părinți, din care și-a cules înțelepciunea și știința. ,Aici a trăit el pentru întâia oară frumusețea afundării în dumnezeire, bucuria duhovnicească a ospățlui ceresc, căruia îi erau părtași pustnicii din singurătate, învredniciți prin har dumnezeiesc, aici a aprofundat practica rugăciunii inimii, făcând din chemarea Numelui lui Iisus centrul rugăciunii sale contemplative".

\footnotetext{
${ }^{8}$ Vezi Г. П. Федотов, Святые Древней Руси, Москва, 1990; И. К. Смолич, Русское монашество: Возникновение. Развитие. Сущность. (988-1917), Москва, 1997.

${ }^{9}$ М. С. Боровкова-Майкова, Нил Сорский, в „История русской литературы в 10 томах", 1941-1956, Т. II, Ч. 1., Литература 1220-х - 1580-х гг., 1945, p. 318.
} 
În cele din urmă a revenit la mănăstirea Sfântului Chiril din Rusia, unde a încercat să pună în practică învățăturile dobândite în Sfântul Munte. Însă, înțelegând că într-o mănăstire mare este dificil să duci o viață isihastă, Nil a adus din Muntele Athos rânduiala vieții în comunități mai mici sau schituri - o a treia formă de viață monahală, pe lângă cele două deja existente: viața cenobitică și cea eremitică. Acest nou mod de viață monahală, intermediar între cenobitism și eremitism, care constituia pentru Nil „cea mai bună formă de organizare a vieții mănăstirești" ${ }^{\prime 10}$, era foarte popular în Muntele Athos în acea perioadă. Sfântul Nil vedea în această formă de monahism şansa unei vieți mai izolate în care monahii puteau să își respecte mai deplin voturile călugărești, evitând ispita materialismului la care erau expuse mănăstirile mari care dețineau proprietăți. El este cel care va iniția un mare curent isihast în spiritul sărăciei monastice absolute ${ }^{11}$.

Cuviosul Nil își întemeiază schitul său în jurul anului 1473, pe malul râului Sora. Locaşul său din pustie ținea o regulă athonită echilibrată. El nu-i lăsa pe monahi să vieţuiască singuri, fără a păstra legătura cu alte persoane, ci dorea ca în fiecare chilie să stea doi sau trei călugări. În acest mod căderile duhovniceşti ale unuia dintre monahi puteau fi observate cu uşurință de ceilalţi locuitori ai chiliei. La scurt timp a fost urmat de mulți doritori de a trăi alături de el în isihie $^{12}$. Nil Sorski promova reformele monahale care să aibă la bază

${ }^{10}$ Я. С. Лурье, Идеологическая борьба в русской публицистике конияа XV начала XVI вв., Москва, 1960, p. 343.

${ }^{11}$ ÎPS Mitropolit Serafim Joantă, Din istoria isihasmului până în secolul XV, în vol. „Persoană și comuniune. Prinos de cinstire Pr. Prof. Acad. Dumitru Stăniloae", Sibiu, 1993, p. 562.

${ }^{12}$ Sfântul Vasile de la Poiana Mărului nota, în veacul al XVIII-lea, în prefața scrierilor Cuviosului Nil Sorski: „Însuşi acest fericit bătrân stareț Nil, spunând multe şi înfricoşătoare cuvinte împotriva celor ce vor să vieţuiască singuri, deşi sunt pătimaşi, laudă foarte tare calea impărătească, spunând că această rânduială şi regulă există în Sfântul Munte al Athosului, unde până astăzi intocmirea chiliilor vechi şi noi arată tuturor exemplul viu al căii împărăteşti. 


\section{Alexandru CUȚCHI}

o viață monahală retrasă și modestă. El milita pentru concentrarea pe lumea lăuntrică și pe experiența personală a credinței ca mod de a ajunge la comuniunea cu Dumnezeu ${ }^{13}$.

Scrierile autentice atribuite Sfântului Nil Sorski sunt: Predanie (Testament către ucenici), Ustav (Tipic mănăstiresc), un material epistolar ce include scrisori către contemporanii săi: Vassian Patrikeev, Gurii Tushin, și neamțul Podol'nyi (denumite Trei Epistole), precum și concisa Mica Epistolă, prefața și postfața Sobornik-ului și, în cele din urmă, Testamentul ${ }^{14}$.

Un loc central printre aceste lucrări îl ocupă Testamentul către ucenici și Ustavul, ce expun în detaliu învățătura despre „lucrarea minții”. Acestea conțin bazele învățăturii non-posesorilor și o expunere detaliată a teoriei desăvârșirii morale - teorie pe baza căreia Sfântul Nil dorea să reconstruiască viața monahismului rus. Fiecare gând al autorului este întărit cu citate din literatura patristică. Toate expunerile sunt pătrunse de smerenia, răbdarea și bunătatea care-1 caracterizau pe ,,marele stareț' - cum era numit Nil de către contemporanii săi ${ }^{15}$. Conform profesorului Job Getcha, unul dintre cele mai mari merite ale Sfântului Nil pentru monahismul rus a constat anume în antologia sa de scrieri ascetice, care au constituit o anticipare a Filocaliei secolului al XVIII-lea ${ }^{16}$. Prin scrierile sale, Sfântului Nil face o primă expunere sumară din Rusia a doctrinei ascetice a Sfinților Părinți ${ }^{17}$.

Fiindcă acolo chiliile, fie cu biserică, fie fără biserică, au toate încăperi pentru doi sau trei, iar nu pentru unul singur" (Sfântul Vasile de la Poiana Mărului, Introduceri în rugăciunea lui Iisus şi isihasm, Ed. Deisis, Sibiu, 2009, p. 157). ${ }^{13} \mathrm{http} / / /$ ro.orthodoxwiki.org/Nil_Sorski (accesat pe 7 mai 2015).

${ }^{14}$ J. N. Martin, Nil Sorsky: The Authentic Writings, trans., ed. and introd. by D. M. Goldfrank, Cistercian Publications, Kalamazoo, Michigan, 2008 (review), în: „Spiritus: A Journal of Christian Spirituality”, Vol. 2, Nr. 9, Fall 2009, p. 257. ${ }^{15}$ М. С. Боровкова-Майкова, op. cit., pp. 318-319.

${ }^{16}$ Prof. Arch. Job Getcha, The Hesychast Spirituality of the Russian Monastic Tradition, http://www.bogoslov.ru/en/text/2372746.html (accesat pe 2 iunie 2015). ${ }^{17}$ Vezi S. M. Jacomon, Saint Nil Sorsky (1433-1508). La vie, les écrits, le skit 


\section{Cuviosul Nil Sorski și principiile sale ascetice}

Sufletul religios al tânărului Nil, înclinațiile sale mistice și căutările teologice nu și-au găsit satisfacția deplină în mănăstirea Sfântului Chiril ${ }^{18}$. În urma pelerinajului efectuat la Sfântul Munte, Sfântul Nil Sorski a introdus în viața monahismului rus medieval ceva nou și pe atunci încă necunoscut. El învăța că întreaga viață a creștinului în dorința de a urma duhul Evangheliei trebuie să tindă spre o desăvârșire continuă. Omul, înzestrat personal cu o voință liberă și conștientă, merge pe această cale, pe calea războiului duhovnicesc, în vederea mântuirii sufletului său. Creșterea interioară, morală și duhovnicească a celui care caută mântuirea se atinge numai prin „rugăciunea minții” și „trezvia inimii”; doar aceste mijloace ale lucrării ascetico-mistice constituie temelia unei vieți creștine active și rodnice. ,Lucrarea trupească, — scrie Nil — rugăciunea exterioară, este nimic mai mult decât frunza; pe când cea interioară, adică lucrarea minții, este fructul" 19 .

În războiul duhovnicesc, ascetul are de a face cu opt patimi principale, pe care trebuie să le învingă în sine, astfel încât, înaintând cu succes pe calea experienței, să ajungă la starea de contemplare mistică, coroana tuturor lucrurilor fiind îndumnezeirea ${ }^{20}$. O luptă

d'un starets de Trans-Volga, (SO 32), Bellefontaine, 1980.

${ }^{18}$ Despre starea mănăstirii Sfântului Chiril-Belozersky în ultimele 2 decenii ale secolului al XV-lea vezi Н. К. Никольский, Общинная и келейная жизнь в Кирилло-Белозерском монастыре в XV и XVI и в начале XVII в., в „Христианское чтение”, 1907, Август, pp. 155-173.

${ }^{19}$ М. С. Боровкова-Майкова, Нила Сорского Предание и Устав, СанктПетербург, 1912, pp. 11-12.

${ }^{20}$ Ibidem, pp. 38-60. Este vorba despre patimile care au fost deja înșirate de către Evagrie Ponticul în Capete despre deosebirea patimilor și a gândurilor, în Filocalia, vol. I, trad. de Pr. Dumitru Stăniloae, Sibiu, 1947, pp. 48-70. Apoi acestea au fost preluate de scriitori ascetici ai unei epoci cu mult mai târzii cum sunt: Nil Sinaitul, Ioan Scărarul, Ioan Casian ș. a. A se vedea, spre exemplu: Ioan Casian, Despre cele opt gânduri ale răutății, în Filocalia, vol. I, trad. de Pr. D. Stăniloae, Sibiu, 1947, pp. 97-123. 
eficientă cu ispitele constă, conform starețului Nil, în ,„păzirea inimii”, în „tăcere” și în ,rugăciunea minţii”. Monahul trebuie să dedice mult timp contemplației mistice, iar cuvintele rugăciunii lui Iisus - „Doamne, Iisuse Hristoase, Fiul lui Dumnezeu, miluiește-mă pe mine păcătosul" - trebuie să fie permanent pe buzele sale ${ }^{21}$.

In ceea ce privește chestiunea proprietăților mănăstirești ${ }^{22}$, Nil susține că monahii ar trebui să trăiască și să se întrețină din rodul propriei munci, împărțind și celor sărmani din cele câștigate. El își mai exprimă o părere foarte interesantă și, totodată, neobișnuită pentru Rusia Medievală: luxul excesiv în decorarea sfintelor lăcașuri este absolut inutil în cult, căci acesta devine deseori un scop în sine, o patimă.

În opinia Cuviosului Nil, viața de schit - acea formă de viață monahală pe care a numit-o ,calea de mijloc” sau „,calea de aur” îi oferă ascetului posibilități mai bune de a-și duce viața în trezvia sufletului, în rugăciune și isihie. El trebuie să-și înceapă ziua cu rugăciune și să-și petreacă tot timpul făcând lucruri bineplăcute lui Dumnezeu: să se roage, să cânte psalmi, să citească Sfintele Scripturi. Este necesar, de asemenea, ca ascetul să fie ocupat cu rucodelia (lucrul mâinilor), în primul rând, pentru a-și menține starea de veghe în permanență, iar în al doilea rând, ca prin munca mâinilor sale să-și dobândească strictul necesar de hrană. Gândul la moarte trebuie să-1 însoțească mereu pe monah, iar întreaga viață duhovnicească trebuie să și-o construiască în așa fel încât să fie gata în orice minut să se înfățișeze înaintea Feței lui Dumnezeu ${ }^{23}$.

${ }^{21}$ Ibidem, pp. 20-24.

${ }^{22}$ „Nicăieri în intregul Răsărit ortodox - scria istoricul A. V. Kartashev problema legitimității proprietăților mănăstirești, în abordarea sa morală și practică, n-a atins o asemenea ascuțime din punct de vedere soteriologic, ca în Biserica Rusă". (A. В. Карташев, Очерки по истории Русской Церкви, Том 1, Москва, 1992, p. 451).

${ }^{23}$ И. К. Смолич, op. cit., p. 55. 


\section{SCHITUL SFÂNTULUI NIL SORSKI CA FENOMEN UNIC AL CULTURII MONAHALE RUSE A SECOLELOR XV-XVII}

Particularitatea și unicitatea schitului Sfântului Nil constau în faptul că acesta este primul schit rus care a existat, pentru o lungă perioadă de timp, ca o mănăstire independentă cu un anumit tipic al său, ustav, și mod de organizare a vieții monahale. În schitul său, chiliile erau așezate la o oarecare distanță una față de cealaltă, cât și față de biserică. Acest principiu se respecta cu strictețe, pentru a nu încălca „tăcerea” și contemplarea călugărilor - ca ,să nu se audă cum cineva, rugându-se, se apropie de Dumnezeu" ${ }^{24}$.

\section{Tipicul (Ustavul) mănăstiresc și Tipicul liturgic}

Tipicul (Ustavul) mănăstiresc al schitului Sfântului Nil, cel care cuprindea principiile de bază ale viețuirii în interiorul mănăstirii, îl constituia, conform cercetătoarei Fairy von Lilienfeld, „Predania” starețului Nil, iar unica analogie mai apropiată de aceasta se poate

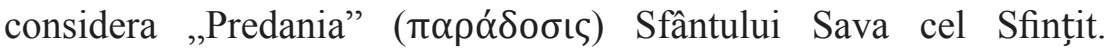
Expunând principiile de bază ale vieții monahale, Cuviosul Nil face referire în scrierea sa la lucrarea Sfântului Ioan Scărarul (acolo unde scrie cum trebuie să se procedeze cu „samovolnicii” ce nu doreau să trăiască după Ustavul mănăstiresc și după învățăturile Sfinților Părinții) ${ }^{25}$, apoi la Sfinții Vasile cel Mare, Varsanufie, Isaac, avva Dorotei (despre milostenia monahală, sărăcie, ascultările mănăstirești și despre regula „,părăsirii chiliilor”), la Sfântul Ioan Hrisostom (despre inutilitatea luxului în biserici).

Testamentul către ucenici al Cuviosului Nil Sorski dă dovadă de tradiționalitate și, în același timp de individualitate, în calitatea sa de tipic mănăstiresc. Din multitudinea de reguli ale vieții monahale

${ }^{24}$ И. И. Плешков, Повесть о Нило-Сорском ските, в „Памятники культуры. Новые открытия. Ежегодник 1976”, Москва, 1977, p. 17.

${ }^{25}$ „Despre unii ca aceștia în Dumnezeiasca Scară se spune că mai bine ar fi alungați, decât să fie lăsați să trăiască după voia lor" (М. С. БоровковаМайкова, Нила Сорского Предание и Устав..., p. 5). 
cuprinse în scrierile patristice, în viețile sfinților, el le-a selectat pe cele pe care le-a considerat ca fiind cele mai necesare pentru a-și feri schitul de influența „lumii” și a ,conflictelor” interne. Printre acestea, un loc important îl ocupă regulile cu privire la renunțarea la proprietăți și la lepădarea de sine. Acestea disting „Predania” lui Nil de cel mai apropiat ca stil și conținut Tipic - cel al Cuviosului Sava cel Sfințit ${ }^{26}$, făcându-1 o scriere originală a literaturii patristice de acest gen.

Tipicul liturgic al schitului de pe râul Sora prevedea ca în fiecare duminică și la praznicele împărătești să se săvârșească ,,priveghere, tedeum și Sfânta Liturghie". Această privegherea dura toată noaptea, după obiceiul tuturor schiturilor și lavrelor. Rânduiala slujbelor săvârșite în schit se deosebea de cea a mănăstirilor cu viață de obște nu doar prin lungime, ci și prin alcătuire, căci, așa cum scria sfântul stareț în Ustavul său: „Una este lucrarea isihiei, iar alta viețuirea obștească" ${ }^{27}$. În cadrul privegherii se citea jumătate de psaltire (în chinovii de obicei se citeau trei catisme), și era un număr mai mare de canoane - patru. Apoi se citea din scrierile Sfinților Părinți și din Viețile Sfinților. Utrenia se termina pe la ora 7. După utrenie și ceasul I toți se duceau pe la chilii. Apoi din nou se adunau la tedeum și la Sfânta Liturghie, urmând ca la final fiecare să-și ceară iertare de la ceilalți și să plece la chilia sa ${ }^{28}$.

Schitul întemeiat de către Cuviosul Nil Sorski în pământurile nordice ale Rusiei corespundea cu tradiția din vechime a viețuirii în schituri atât prin caracterul organizării, amplasare, Ustav, cât și prin nivelul vieții duhovnicești. Acest schit a jucat pentru monahismul rus același rol ca și schitul Sfântului Macarie cel Mare pentru monahismul primelor secole ale creștinismului.

${ }^{26}$ Фери фон Лилиенфельд, О литературном жанре сочинении Нила Сорского, в „ТОДРЛ”, Том 18, Москва, 1962, pp. 82-94. Aici sunt analizate tipologia Tipicurilor mănăstirești și gradul de apropiere al Tipicului Cuviosului Sava cel Sfințit de „Predania” lui Nil Sorski.

${ }^{27}$ М. С. Боровкова-Майкова, Нила Сорского Предание и Устав..., p. 26.

${ }^{28}$ Е. В. Романенко, Нил Сорский и Традиции Русского Монашества, Москва, 2003, p. 151. 


\section{Organizarea activităților gospodărești ale schitului}

O condiție importantă și necesară pentru păstrarea rostului principal al viețuirii în schit, care să nu tulbure ,isihia” și contemplația monahilor, era organizarea vieții gospodărești în mănăstire, de aceea organizarea internă a schitului Sfântului Nil Sorski avea o serie de particularităti, caracteristice pentru toate mănăstirile de acest tip. Sarcina de a avea grijă ca monahii să nu aibă ,preocupări și griji lumești” aparținea unuia dintre bătrânii din schit numit „zidar”, căci el era cel care „zidea” viața mănăstirii, fiind însărcinat cu treburile gospodărești și administrative. Astfel de responsabilități de „zidărie” existau și în schiturile egiptene (econom), palestiniene, athonite (dikeos). Primul „zidar" al schitului de pe râul Sora a fost însuși starețul Nil. Acesta se mai ocupa de primirea monahilor în schit, urmărea religiozitatea și evlavia călugărilor și respectarea ustavului mănăstiresc ${ }^{29}$.

Una dintre particularitățile organizării vieții gospodărești a schitului Sfântului Nil a fost sprijinul din partea statului, de care schitul a beneficiat din anul 1515 și până la începutul secolului al XVIII-lea. Căci, a te hrăni doar din rucodelie (care pentru călugării schitului Sfântului Nil consta în scrierea de cărți, pictarea de icoane, grădinărit) în condițiile existente în partea de Nord a Rusiei era cu mult mai dificil decât în schiturile din Egipt, Țara Sfântă și Athos. De acest aspect a ținut cont Nil când a permis mănăstirii sale să primească „ajutoarele necesare, dar nu mai mult decât era nevoie”" ${ }^{30}$. Principiul „,non-posesiunii” era respectat cu rigurozitate în schit. Până aproape de secolul al XIX-lea schitul Sfântului Nil Sorski nu deținea nici pământ arabil, nici animale, iar sate n-a avut în posesie niciodată ${ }^{31}$.

Prin propunerea schitului ca formă de organizare a vieții monahale, starețul Nil nu intenționa să transforme toate mănăstirile rusești în schituri sau să desființeze viața cenobitică. Punându-1 în

\footnotetext{
${ }^{29}$ Ibidem, p. 166.

${ }^{30}$ Н. К. Никольский, op. cit., pp. 158-159.

${ }^{31}$ М. С. Боровкова-Майкова, Нила Сорского Предание и Устав..., p. 6.
} 
contrast pe Nil Sorski cu Iosif de Volokolamsk, cercetătorii de regulă remarcă faptul că Sfântul Nil urma, în această privință, tradiția Sfinților Părinți ai primelor veacuri, iar Sfântul Iosif se sprijinea pe tradiția națională rusă, așa cum s-a dezvoltat aceasta până în secolul al XV-lea ${ }^{32}$.

\section{CONSIDERAT,II FINALE}

Sfântul Nil Sorski a fost fondatorul și organizatorul unui tip nou de mănăstire pentru istoria monahismului rus - schitul. Acesta reprezintă o formă cu totul specială de viață monahală ce reunește în sine trăsăturile, pe de o parte, ale vieții pustnicești, pe de altă parte, ale chinoviei. Această combinare asigură condițiile necesare pentru păstrarea sensului de bază al viețuirii în schituri: ,lucrarea minții”.

Optând pentru o formă a vieții monahale care era, în opinia sa, cea mai potrivită, Sfântul Nil se baza pe experiența personală și pe cunoașterea profundă a tradițiilor. În colecțiile sale hagiografice sunt prezentate viețile sfinților care au întemeiat diverse forme de viață monahală: pustnicii egipteni Pavel Tebeul și Antonie cel Mare, Arsenie cel Mare; organizatorii lavrelor palestiniene: Ilarion cel Mare, Hariton Mărturisitorul, Sava cel Sfințit, Eftimie cel Mare; întemeietorii viețuirii în comun: în Egipt - Pahomie cel Mare, în Țara Sfântă - Teodosie cel Mare, în Athos - Atanasie Athonitul. Schitul Sfântului Nil poate fi numit schitul clasic, după tipul schiturilor timpurii din Egipt, Athos și Țara Sfântă. Și prin aceasta el constituie un fenomen unic în istoria monahismului rus din secolele XV-XVII.

O bună cunoaștere a tradiției Sfinților Părinți, cât și a celei ruse contemporane, datorate propriei experiențe acumulate prin pelerinaje, studierii permanente a vieților sfinților; voința fermă a starețului Nil de a-i urma întru totul pe Sfinții Părinți - toate acestea

\footnotetext{
${ }^{32}$ Иоанн Калинин, Описание Нило-Сорской мужской общежительной пустыни Новгородской Епархии, Москва, 1913, pp. 19-20.
} 
s-au concretizat în modul de organizare a schitului său. Însăși apariția acestuia la sfârșitul secolului al XV-lea și existența sa îndelungată ca mănăstire de tip schit vorbesc despre aceea că monahismul rus s-a dovedit a fi capabil să perceapă acele tradiții clasice ale „lucrării minții” și ale viețuirii în schituri, unicul depozitar al cărora rămânea în acea vreme Muntele Athos.

\section{Bibliografie:}

1. Боровкова-Майкова, М. С., Нила Сорского Предание и Устав, Санкт-Петербург, 1912.

2. Боровкова-Майкова, М. С., Нил Сорский, в „История русской литературы в 10 томах, 1941-1956", Т. II, Ч. 1., Литература 1220-х - 1580-х гг., 1945.

3. Fedotov, G. P., The Russian Religious Mind, II, Cambridge, MA, 1946.

4. Федотов, Г. П., Святые Древней Руси, Москва, 1990.

5. Флоровский, Г. В., Пути русского богословия, Париж, 1983.

6. Хоружий, С. С., О старом и новом, Алетейя, Санкт-Петербург, 2000.

7. Jacomon, S. M., Saint Nil Sorsky (1433-1508). La vie, les écrits, le skit d'un starets de Trans-Volga, (SO 32), Bellefontaine, 1980.

8. Joantă, Serafim, Din istoria isihasmului până în secolul $X V$, în vol. „Persoană și comuniune. Prinos de cinstire Pr. Prof. Acad. Dumitru Stăniloae", Sibiu, 1993.

9. Калинин, Иоанн, Описание Нило-Сорской мужской общежительной пустыни Новгородской Епархии, Москва, 1913.

10. Карташев, А. В., Очерки по истории Русской Церкви, Том 1, Москва, 1992.

11. Лилиенфельд, Фери фон, O литературном жанре сочинении Нила Сорского, в „Труды Отдела Древнерусской Литературы” („ТОДРЛ”), Том 18, Москва, 1962.

12. Лурье, Я. С., Идеологическая борьба в русской публицистике конца XV - начала XVI вв., Москва, 1960.

13. Martin, J. N., Nil Sorsky: The Authentic Writings, trans., ed. and introd. By David M. Goldfrank, Cistercian Publications, Kalamazoo, 
Michigan, 2008 (review), în: „Spiritus: A Journal of Christian Spirituality", Volume 2, Number 9, Fall 2009.

14. Муравьёв, Андрей, Русская Фиваида на Севере, СанктПетербург, 1855.

15. Никольский, Н. К., Общинная и келейная жизнь в КириллоБелозерском монастыре в XV и XVI и в начале XVII в., в „Христианское чтение”, 1907, Август, pp. 155-173.

16. Плешков, И. И., Повесть о Нило-Сорском ските, в „Памятники культуры. Новые открытия. Ежегодник 1976”, Москва, 1977.

17. Романенко, Е. В., Нил Сорский и Традиции Русского Монашества, Москва, 2003.

18. Sfântul Evagrie Ponticul, Capete despre deosebirea patimilor și a gândurilor, în Filocalia, vol. I, trad. de Pr. D. Stăniloae, Sibiu, 1947.

19. Sfântul Ioan Casian, Despre cele opt gânduri ale răutății, în Filocalia, vol. I, trad. de Pr. D. Stăniloae, Sibiu, 1947.

20. Sfântul Vasile de la Poiana Mărului, Introduceri în rugăciunea lui Iisus şi isihasm, Ed. Deisis, Sibiu, 2009.

21. Смолич, И. К., Русское монашество: Возникновение. Развитие. Сущность. (988-1917), Москва, 1997.

22. Špidlik, Thomas, Joseph de Volokolamsk; un chapitre de la spiritualité russe, în „Orientalia Christiana Analecta”, vol. 146, Roma, 1956.

\section{Surse web:}

1. Fedotov, G. P., A Treasury of Russian Spirituality, New York, 1948, http://www.holytrinitymission.org/books/english/russian spirituality_fedotov.htm\#_Toc46671173 (accesat pe 28 mai 2015).

2. Getcha, Job, The Hesychast Spirituality of the Russian Monastic Tradition, http://www.bogoslov.ru/en/text/2372746.html (accesat pe 2 iunie 2015).

3. http://ro.orthodoxwiki.org/Nil_Sorski (accesat pe 7 mai 2015). 